\title{
Applying Modern Literary Theories to Pre-Islamic Arabic Poetry: A Critical Analysis of the "Rite of Passage" Model
}

\author{
Hikmet Yaman*
}

Modern Edebî Kuramları İslamiyet Öncesi Arap (Cahiliye) Şiirine Uygulamak: “Geçiş Âyini” Modelinin Eleștirel Tahlili

İslamiyet öncesi (Cahiliye) Arap şiiri modern zamanlarda Batı'da üretilmiş çeşitli tenkitsel edebî kuramların yöntem ve bakış açılarıyla tahlil edilmeye çalışılmaktadır. Sözlü şiir kuramlarından yapısalcı ve antropolojik edebî kuramlara varıncaya kadar farklı tenkitsel uygulamalar bu şiir geleneğine tatbik edilmektedir. Bu tür edebî tatbikatları yapan ilim insanları arasından Kemal Abu Deeb, Adnan Haydar ve özellikle de Suzanne Pinkney Stetkevych temsil kabiliyeti yüksek örnekler olarak öne çımaktadır. Abu Deeb ve Haydar hususi yapısalcı tahlil tekniklerini Cahiliye şiirine uygularken Stetkevych, Arnold van Gennep tarafından "geçiş âyini" (rite de passage) şeklinde ifadeye dökülen paradigmanın İslamiyet öncesi Arap şiirinin anlaşılıp yorumlanmasında daha makul ve uygulanabilir bir yöntem olduğunu ileri sürmektedir. Stetkevych'in yaklaşımina göre klasik Arap kasidesinin üç temel bölümü (nesîb, rahîlve fahr) geçiş âyinin üç aşamasıyla (ayrılık, eşiktelik, yeniden bir araya gelme) genel bir uyum arzetmektedir. $\mathrm{Bu}$ makalede bu tür Batı menşeli edebî kuramların ve onların retorik unsurlarının Cahiliye şiirinin tercüme ve tahlilinde ne derece etkin, yetkin ve başarılı olabilecekleri sorgulanmaktadır. Daha tafsilatlı bir biçimde Stetkevych'in argümanları üzerine yoğunlaşarak makale İslamiyet öncesi Arap şiirinin kendine mahsus edebî özelliklerine dikkat çekmekte ve söz konusu kuramların bu bağlamdaki yöntem ve çıkarımlarının tutarlılığını sorguya açmaktadır. Etraflıca düşünülmeden gelişigüzel tasnif ve mukayeseler üzerinden gerçekleştirilen bu uygulama teşebbüsleri Cahiliye şiirinin nevi şahsına münhasır kültürel ve edebî boyutlarını açıklamaktan ziyade asli anlam ve bağlamlarını çarpıtmakta ve gerçekte ilave zorluk ve kapalılıklar üretmektedir. Stetkevych'in

* Associate Professor, Marmara University, Faculty of Theology, Department of Philosophy and Religious Studies, History of Islamic Philosophy.

ORCID oooo-ooo1-5894-2453 yaman.hikmet@marmara.edu.tr

I dedicate this study to the beloved memory of my late teacher Prof. Wolfhart P. Heinrichs of Harvard University. 
bu meyandaki çalışmaları içerisinden seçilen bir dizi örnek metin temelinde makale, onun İslamiyet öncesi Arap edebî teamülleri ile Batı edebî geleneklerindeki retorik unsurlar arasında zorlama bir şekilde benzetme ve yakınlaştırmalar yaptığını dile getirmekte ve böylece konunun gereksiz ve karmaşık mecralara sürüklendiğini örnekleriyle birlikte ifade etmektedir. Stetkevych'in ileri sürdügü çıkarımları ve genellemeleri Arap şiirinin geleneksel otoriteleri tarafından ortaya konmuş olan izah ve yorumlarla karşılaştıran makale, bu işlemi klasik Arap şiirinin iki müstesna kasidesi örnekliğinde hususen icra etmektedir: İmruülkays'in Múallaka’sı ve Ka'b b. Züheyr'in Kașîdetü’bürde'si. Makalede ayrıca Stetkevych'in İslam'da şairlerin lanetlenmesi konusundaki mütalaaları değerlendirilmekte ve mevzunun tarihi ve bağlamsal özelliklerine vurgu yapılmaktadır.

Anahtar kelimeler: İslamiyet öncesi Arap (Cahiliye) şiiri, kaside, edebî kuramlar, edebî tenkit, yapısalcılık, antropolojik edebî kuramlar, geçiş âyini, sözlü şiir, İmruülkays, Múallaḳa, Ka‘b b. Züheyr, Kasșidetüll-bürde, şairlerin lanetlenmesi.

\section{Introduction: Applicability of Western Literary Theories to Pre-Islamic Arabic Poetry}

Various critical literary approaches have been applied in translation and analysis of pre-Islamic Arabic poetry. Ranging from oral poetry theories to structuralist and anthropological literary theories, ancient Bedouin poetry has been subject to diverse critical applications.

On the basis of the fact that the pre-Islamic Arab poet composed his poems mostly without the help of writing, and that his performance was originally oral poetry recited by him and his transmitters (rāwìs) on various occasions, his compositions have been analyzed in light of the oral poetry of other peoples. The improvised epic poetry of illiterate folk-singers of the southern Slavs and of the Homeric poems, which have been examined by Milman Parry and Albert B. Lord, ${ }^{1}$ are among the examples of such comparable oral literary compositions. ${ }^{2}$ Despite such similarities, nevertheless,

1 Lord, The Singer of Tales.

2 In their works, The Oral Tradition of Classical Arabic Poetry: Its Character and Implications and "Oral Composition in Pre-Islamic Arabic Poetry," 1-53, Michael Zwettler and James T. Monroe have respectively attempted to apply the theory of Parry and Lord to the Jâhili poetry. Criticizing the applicability of such theory to ancient Arabic poetry, Gregor Schoeler argues that the improvised poetry in question is composed and recited on various occasions quite differently. He follows, "If the oral poetry theory were applicable to ancient Arabic poetry, then even the most complicated polythematic qașidas would be improvised poems, presented in a different version with every recitation. However, some proponents of this theory concede that a qașida consisted of a more or less solid core memorized by the poet or transmitter of which he is said to have improvised at each recitation." Schoeler, "Oral Composition," II, 592-593. 
ancient Arabic poetry differs considerably from them in its peculiarities. Most significantly, pre-Islamic poetry consists more specifically of lyric rather than of epic poetry.

In fact, the epic poetry attempts in Arabic literature were inspired by Persian influence and emerged many years after the Hegira. It was already during the second century of the Hegira that Abān al-Lāhiqīi (d. 200/815-16) transposed some stories including Kalìla and Dimna and Sindbādnāme into Arabic verse.

At the same time, there are other characteristics of Jähili poetry that distinguish it from epic poetry. For example, the Bedouin poet in general had little taste for fiction. Instead, he was mostly interested in relating facts and actual events. Even in unreal occurrences, he preferred to keep his utterances close to actual observations rather than constructing fictitious events. The Arab poet and his audience did not have the patience to waste much time on a single subject. He used to compose rather short pieces on a single theme and pass quickly on to another. As a result of this, the mastery of the author

Schoeler further points out that the existence of many pre-Islamic poems in different versions with various variants does not necessarily make reasonable the applicability of the oral poetry theory to ancient Bedouin poetry. Such poems, nevertheless, have a close link to their author indicating a specific and individual style. There are some other exclusive reasons to prevent the applicability of the oral poetry theory: above all, given the complicated meters and rhymes that are subject to strict rules, the qașida cannot be considered a typical improvised poetry. In addition, there are records that relate for how long time certain poets would spend on a qașida, even in some cases up to one year. The improvised poems in ancient Bedouin tradition are short pieces ( $\left.q_{i t}{ }^{\prime} a s\right)$, which are often composed in a simpler meter, rajaz, rather than qașidas. Schoeler concludes, "In the case of the ancient Arabic qașida we are dealing thus with a special kind of oral poetry for which a carefully planning poet is characteristic, and if one looks for a comparison this poetry could most easily be put on the same level with the old Icelandic poetry of the scalds or the lyrics of the troubadours. The different versions of specific poems and the richness in variants can be partly explained by the long oral, or at any rate philologically uncontrolled, transmission. Additionally, the poets may occasionally have revised their qașidas and successively 'published' different versions of them. Finally, it is known that some rāwis thought it to be their right to treat the transmitted poetry rather liberally. Sometimes they were even invited by their masters to improve the poems in certain places. However, the various versions of a qașida arising from revision and correction by poets and rāwīs cannot be compared with the improvisations of the singers of the tales that are newly created in each new performance." Schoeler, "Oral Composition," II, 592-593. For another noteworthy criticism of the "oral theory" in analyzing the qașida see studies by Thomas Bauer, "Formel und Zitat: Zwei Spielarten von Intertextualität in der altarabischen Dichtung," 117-138 and "Wie fängt meine Qașìda an? Formelhafte und nicht-formelhafte NasībEinleitungsverse," 50-75. I am thankful to the anonymous reviewer of this article for bringing Bauer's studies to my attention. 
was dependent upon the beauty of single verses, instead of upon the whole poetic structure. ${ }^{3}$

Suzanne Pinckney Stetkevych offers another method to analyze pre-Islamic Arabian poetry. ${ }^{4}$ Criticizing specific structuralist techniques of analysis of Jāhilì poetry by certain contemporary scholars-i.e., Mary C. Bateson, Kemal Abu Deeb, and Adnan Haydar-she proposes that the "rite of passage" paradigm formulated by Arnold van Gennep (d. 1957) and elucidated by Victor Turner, Mary Douglas, and others could provide a more applicable method to understanding the classical Arabic qașida. For, she argues, the three parts of the qașida - the nasib, rahìl, and fakhr-correspond to the three stages of the rite of passage: separation, liminality, and reaggregation.

In which way and to what extent do the similarities between pre-Islamic Arabic poetry and other poetic traditions justify the applications of the aforementioned and some other Western literary theories to pre-Islamic Arabic poetry and thus lead us to a better way of understanding of this literary tradition? How can we clarify its poetic peculiarities by applying various literary theories without making deceptive and misleading generalizations? What could be the criteria that determine the applicability of certain literary theories to the study of Jahili poetry? Although in general I appreciate and even to a certain extent admire the industrious attempts at trying to integrate Arabic literature into world literature, in this article, I will invite critical attention to the reconsideration some of their conclusions. Focusing more specifically on Stetkevych's writings, I will discuss some of her arguments comparing them to classical interpretations by indigenous literary authorities. I am particularly interested in one aspect of her arguments-i.e., their applicability to Jāhilī poetry and the consistency of her conclusions in this regard-rather than in questioning her writings in light of Western literary theories themselves.

In her consecutive articles, Stetkevych first criticizes Bateson's attempt ${ }^{5}$ to apply a linguistic structuralist analysis to five of the Múallaqāt: those of Imru' al-Qays, Tarafa, Zuhayr, Labīd, and 'Antara. Stetkevych asserts that due to Bateson's inadequate acquaintance with the Arabic language and literature, her work cannot be considered a scholarly contribution to the understanding of the Jāhili poetry, neither do Bateson's analyses go beyond the level of a summary of the poems at a most superficial level. ${ }^{6}$

3 See editor's introduction in al-Jurjānī, Asrār al-Balāgha, 1-2.

4 Stetkevych, "Structuralist Analyses of Pre-Islamic Poetry," 85-107.

5 Bateson, Structural Continuity in Poetry.

6 Stetkevych, "Structuralist Analyses of Pre-Islamic Poetry," 85-86. 
Second, Stetkevych takes up Kemal Abu Deeb's two successive structuralist analyses of two pre-Islamic poems, the Mu'allaqa of Labìd and of Imru' alQays, according to Levi-Strauss's technique of myth analysis. ${ }^{7}$ She concludes that both because of Levi-Strauss's own methodological problems as well as Abu Deeb's vague and inconclusive attempt to organize the elements of the poems into "bundles of relations," this application presents unsatisfactory conclusions. ${ }^{8}$

And third, Stetkevych evaluates Adnan Haydar's extensive attempts to analyze the Mu'allaqa of Imru' al-Qays in the light of Vladimir Propp's examination of Russian folktales. ${ }^{9}$ She asserts that due to radical difference between the two literary traditions and their rhetorical elements, Haydar's efforts do not provide concise and original conclusions. She explains that the main literary characteristic of the Jāhili poem is its metaphorical quality, rather than its being a myth, folktale, or ritual in metered and rhymed form. ${ }^{10}$

As for her own argument, Stetkevych introduces anthropological analysis and literary criticism to analyze Jāhilì poetry. In her view, unlike LeviStrauss's technique of myth analysis, anthropological theories shed light on the logical and metaphorical thought that bring about totem, ritual, and myth, and their relationship to social order. In this regard she proposes the concept of rite de passage, or "the rite-of-initiation" of modern anthropology along with its affiliated themes of "death and rebirth, pollution and purification" as a "paradigmatic or metaphoric model for the thematic and poetic structure of the pre-Islamic qașida."11

7 Abu Deeb, "Towards a Structural Analysis of Pre-Islamic Poetry," 148-84, and "Towards a Structural Analysis of Pre-Islamic Poetry (II): The Eros Vision," 3-69.

8 Stetkevych, "Structuralist Analyses of Pre-Islamic Poetry," 86-94. Stetkevych closes her criticism of Abu Deeb's application, "It should be evident that the relationship between the themes, images, and structure of the pre-Islamic qașida are complex metaphorical ones often operating on several semantic levels; they derive from an intricate interplay of traditional imagery, myth, ritual, and archetype. Thus the arbitrary classification of the elements involved in this complicated and often ambiguous web of meaning and metaphor into simple, literal oppositions and mediations quickly deteriorates into a meaningless mechanical exercise." Stetkevych, "Structuralist Analyses of Pre-Islamic Poetry," 94 .

9 Adnan Haydar, “The Mu'allaqa of Imru' al-Qays: Its Structure and Meaning, I," 227-261 and "The Mu'allaqa of Imru' al-Qays: Its Structure and Meaning, II," 51-82.

10 Stetkevych, "Structuralist Analyses of Pre-Islamic Poetry," 94-98.

11 Stetkevych, "Structuralist Analyses of Pre-Islamic Poetry," 98. It should be mentioned that Stetkevych's arguments in this context have already been challenged in modern studies by a number of scholars including Renate Jacobi, Julie S. Meisami and Shawkat M. Toorawa. Jacobi, for instance, wrote a highly critical review of The Mute Immortals Speak: Pre-Islamic Poetry and the Poetics of Ritual in Bibliotheca Orientalis 53 (1996), 
Stetkevych makes an analogy between the three parts of the qașida: the nasib comprising the description of the poet's beloved, the mourning over her departure, and the abandoned encampment; the rahil comprising the difficulties of the desert journey, the description of the poet's she-camel and other animals, and the fauna of the desert; and the fakhr comprising the praise of the poet and his tribe, and the three stages of the rite of passage: separation, liminality, and reaggregation in accordance with van Gennep's formulation. In the following pages of her article, Stetkevych articulates her argument on the basis of the examples of the Mu'allaqàt of Labìd and Imru' al-Qays. Finally, she asserts that without trying to reduce the pre-Islamic qașida to a metered and rhymed rite of passage, she attempts to demonstrate the parallelism of structure and imagery between the classical Arabic qașìda formulated by the traditional Arabic critics and the rite of passage as formulated by van Gennep and his successors. The two literary approaches share "a single archetypal pattern." This "almost universal pattern," Stetkevych argues, explains the significance of many obscure details of imagery and the ritual function of poetry in ancient Bedouin society. Furthermore, it enables us to perceive the amazing persistence and ongoing domination of the classical Arabic qașida. ${ }^{12}$

In a subsequent article, Stetkevych proposes that the poetry of the Șa' $\bar{a} l i \bar{k}$, the "brigand poets", can also be interpreted according to van Gennep's formulation of the rite of passage. ${ }^{13}$ Although the Su'lük poem does not conform to the classical Arabic tripartite qașida model, the nasīb-rahìl-fakhr, formulated by Ibn Qutayba (d. 276/889) and others, she claims that it can be considered in terms of the same paradigm as "a failed or aborted rite of passage" (rite de passage manqué). In this case, the poet does not achieve reintegration into the community. Instead, the temporary difficulties of the liminal state become his permanent way of life. The Șu'lük poem contains elements of the nasìb and the rahill, but not of tribal fakhr. It does not celebrate tribal social values; rather, it favors anti-social tendencies. Taking Ta'abbața Sharrā as a case study and comparing his encounter with the ghìl to that of Oedipus

270-273. Meisami, likewise, presented quite negative evaluations of Stetkevych's discussions on this subject matter throughout her book Structure and Meaning in Medieval Arabic and Persian Poetry. Toorawa, in his part, wrote a very critical review of Reorientations: Arabic and Persian Poetry in Journal of American Oriental Society 117:4 (1997), 759-762 and questioned the consistency of Stetkevych's arguments in this edited work. I am thankful to the anonymous reviewer of this article for reminding me of such earlier criticisms directed to Stetkevych's theories in this context.

12 Stetkevych, "Structuralist Analyses of Pre-Islamic Poetry," 98-107.

13 Stetkevych, "The Șu'lūk and His Poem," 661-678. 
with Sphinx, Stetkevych discusses the symbols and metaphors of deviation from the prescribed course of passage in terms of psycho-social development. Thus together with the akhbār (historical-anecdotal records) related to Ta'abbata Sharrā, she highlights the differences between both the Șu'ūk way of life and regular tribal social life, as well as between the Șulük poem and the classical qașida pattern. She finally concludes that the Șu'lük deviates from the prescribed tribal social pattern just as his poem deviates from the classical qașida form. ${ }^{14}$ According to her interpretation, in the final analysis, nevertheless, the Șulük confirms von Gennep's formulation of the rite of passage with the exception that it lacks the third process: reaggregation.

\section{The Mu'allaqa of Imru' al-Qays in Context}

In her work, The Mute Immortals Speak, ${ }^{15}$ Stetkevych's interpretive skills reach their zenith when she analyzes the Mu'allaqa of Imru' al-Qays in light of the $a k h b \bar{a} r$ that accumulated around the name of the poet. She does not embrace a literal historical connection between the poem and the akhbār regarding the poet, but neither is she inclined to ignore the literary connection between them. She asserts that the akhbär records related to Imru' al-Qays have generated "a persona of tragic and mythic proportions." On the basis of the dominant themes and patterns that might help understand the Mu'allaqa on levels beyond the literal, she argues that 'the akhbār of Imru' al-Qays are informed by the now-familiar ritual pattern of blood vengeance and, further, that his Mu'allaqa shares the same ritually determined structure."16 For, the poet's royal Kindite lineage and its history, the regicide of his father, his rebellious and illicit youth prior to his father's death, and his vow for vengeance and excessive quest to avenge his father are recognizable as the constituents of the blood-vengeance ritual. ${ }^{17}$ Stetkevych calls attention to the parallelism between the murder of Imru' al-Qays's father and those of Oedipus, Julius Caesar, Hamlet, and Macbeth, in each of which "treachery" is involved. The murders signal the failure of fertility on both natural and political levels. She further considers Imru' al-Qays's banishment by his father due to the poetry he had composed about [his cousin] Fātima, his father's attempt to have him killed, and then his expulsion from his family as similar elements of the blood-vengeance ritual. ${ }^{18}$

\footnotetext{
14 Stetkevych, "The Șu'lūk and His Poem," 661-678.

15 Stetkevych, The Mute Immortals Speak.

16 Stetkevych, The Mute Immortals Speak, 241.

17 Stetkevych, The Mute Immortals Speak, 242.

18 Stetkevych, The Mute Immortals Speak, 242.
} 
In order to establish a historical connection between the Mu'allaqa of Imru' al-Qays and the persona of the poet created by the akhbār, Stetkevych repeats Ibn Qutayba's accounts placing the composition of this poem in the midst of the poet's disobedient youth, right after his frolic with the virgins at Dārat Juljul. ${ }^{19}$ Given this historical premise, we would expect Stetkevych to have explained how this poem could be a blood-vengeance ritual while the father is still alive and the son is drinking and enjoying his life with girls. Obviously, the son has not uttered his proverbial dictum, "Wine today, business tomorrow (al-yawma khamrun wa ghadan amrun)," as he does upon hearing of his father's death. ${ }^{20}$ This does not mean we should consider the $a k h b \bar{a} r$ as unquestionable historical records, but since Stetkevych agrees with Ibn Qutayba on the time period when the poet composed the poem, which is apparently before his father's death, her argument contradicts itself from the beginning. She does not propose the possibility that the Mu'allaqa of Imru' al-Qays that we have today may in fact not represent a single poem composed by the poet, since it may be several poems of Imru' al-Qays combined by later literary scholars into a single one. Had she suggested this, her argument would have had more solid historical background, as well as a more logical foundation, and hence she would be free from such contradiction.

In her following lines, Stetkevych refers to van Gennep's rite of passage and Hubert's and Mauss' rite of sacrifice as further structural paradigms, and uses Theodor Gaster's formulation of the seasonal pattern of rite and myth. She asserts that Gaster's pattern is identical to the "devitalization - revitalization" model that she has "established" for the ritual of blood vengeance. Likewise, she concludes, "In his Mu'allaqa Imru'al-Qays has metaphorically sublimated the blood vengeance paradigm to produce a poem that goes beyond the immediate tribal sacrificial level to assume the mythic and cosmic proportions of Gaster's paradigm." 21

Commenting on the opening line of the qașida, "Stop [my] two friends, let us weep at the memory of a beloved and [her] abode at the place where the sands twist to an end between al-Dakhūl and Hawmal," Stetkevych asserts that this is perhaps a first hint that the theme of revenge underlies the poem. Given the aforementioned historical relationship between poet and poem, however, we still need a response to the question of why and from whom he was trying to take revenge on his living father? Relying on Haydar's etymologies of the names, siqt al-liwā, al-Dakhūl, and Hawmal,

19 Ibn Qutayba, al-Shi'r wa al-Shu'arä', 51.

20 Stetkevych, The Mute Immortals Speak, 245.

21 Stetkevych, The Mute Immortals Speak, 258-59. 
Stetkevych introduces the argument that these names refer to "an apposite expression of 'mortification,' in Gaster's terms -the failure of natural fertility- or, in terms closer to the qașida, the failed relationship between the poet and his erstwhile mistress or death of the marthï." 22 In her view, siqt (saqata al-janinu=the fetus miscarried, aborted) suggests miscarriage between alDakhūl (dakhl=sexual penetration) and Hawmal (haml=pregnancy), and thus she continues, "in these terms the opening hemistich conveys attempted revitalization through the shedding of tears, through memory and recollection, counterbalanced by an etymological subtext of barrenness and failure (Gaster's mortification) in the second." ${ }^{23}$

As a very traditional opening line of a poem widely considered to be one of the finest examples of Bedouin poetry, this verse has attracted extensive attention of classical Arabic literary critics and commentators. Most often their interpretative stress falls mainly on the use of the dual imperative form ( $q$ if ā) about which they present a threefold explanation: a) through the dual form the poet is addressing his two companions; b) the poet is addressing one companion but using the dual form, which was a common rhetorical usage among them; c) the poet is using the dual form ( $q i f \bar{a})$ as an intensifier or energetic (qifan). They exemplify similar traditional usage of the dual form through other poems and Qur'ānic quotations. ${ }^{24}$

In Stetkevych's view, the first verse alludes to the failure of man/culture and it is juxtaposed in verse 2 and 3 to "the vitalizing power of nature." The traces have not been completely effaced but preserved by the blowing of the north and south winds (lam ya'fu rasmuhā li-mā nasajathā min janūbin wa shamiali). This implies that "culture fails and fades while nature preserves and creates." 25 The place-names suggest the fecundity of nature, for Tūdị, from the root $w$ - $d-h$ (clarity), and al-Miqrāt, a pool where water gathers entail such readings. The droppings of gazelles (ba'ar al-ar'äm) are likened to peppercorns (habb fulful), that is, "the dung of decay of nature now serves as a preservative for nature as spice does for culture." Thus, what we have in verse 3 is an element of preservation, which is the essence of differentiation between the raw and cooked. The words, tahammalu (loading up) and samurāt (a certain kind of tree) imply pregnancy (haml) and menstruation (hä dat

22 Stetkevych, The Mute Immortals Speak, 259.

23 Stetkevych, The Mute Immortals Speak, 259-60.

24 Al-Anbārī, Sharh al-Qașāìd al-Sab` al-Ṭiwāl al-Jāhiliyyāt, 15-20; al-Naḥhās, Sharh alQașā̉id al-Tis' al-Mashhūrāt, 98-100; al-Zawzanī, Sharh al-Mu'allaqāt al-Sab', 7; al-

Tibrīzī, Sharh al-Qașäid al-'Ashr, 5-7.

25 Stetkevych, The Mute Immortals Speak, 260. 
al-samurāt) respectively. In this way, the poet expresses his physiological response to colocynth (hanzal). ${ }^{26}$

Stetkevych further asserts that together with the following three lines of the qașida,

The opening four verses in a multivocity of symbol, allusion, etymology, and simile convey a message of the failure and fading of human fertility, of culture, the trace of which is preserved by nature, which in turn has assumed the attributes of cultures -spices, weaving. If the absence of the beloved and the departure of her tribe offer a clear expression of the separation phase of the rite of passage, its counterpart in the mortification phase of the seasonal pattern 'when one lease on life has drawn to a close and the next is not yet assured' is given equally convincing expression. ${ }^{27}$

It is not easy to grasp Stetkevych's primary intention throughout her arguments. Does she intend to explain the poem or just to double its already-problematic complexity? So far as her etymological suggestions are concerned, I have not been able to find any classical interpretations to support her arguments. Although they should not be expected to deal with and solve every single literary issue, it is interesting that none of the classical authorities whose works I have consulted present such readings regarding al-Dakhūl, Hawmal, Tūḍih, and al-Miqrāt. They simply consider them as certain place-names. ${ }^{28}$ Nor do they suggest any sexual interpretations for the words tahammalu and samurät. They take the former in the sense of irtahalu and the latter as a certain kind of tree. ${ }^{29}$ Apparently, they all seem to have failed to mention and understand many subtle and deep meanings behind these words in their explanations. On the whole, given the context of the qașida, it makes quite reasonable sense to consider the siqt al-liwa as a certain place situated between four other places. The use of $f a$ - at the beginning of the second line supports such reading, for the $f a$-indicates the verse is directly linked to verse $1 .^{30}$ The poet is weeping at the memory of

26 Stetkevych, The Mute Immortals Speak, 260.

27 Stetkevych, The Mute Immortals Speak, 260.

28 Al-Anbārī, Sharh al-Qașāid al-Sab al-Ṭiwāl al-Jāhiliyyāt, 20-23; al-Naḥhās, Sharh al-Qașǟid al-Tis' al-Mashhūrāt, 100-01; al-Zawzanī, Sharh al-Múallaqāt al-Sab', 8; alTibrīzī, Sharh al-Qașā’id al-'Ashr, 7.

29 Al-Anbārī, Sharh al-Qașāìd al-Sab al-Ṭiwāl al-Jāhiliyyāt, 23; al-Naḥhās, Sharh alQașā’id al-Tis' al-Mashhūrāt,102; al-Zawzanī, Sharh al-Mu'allaqāt al-Sab',7-8; al-Tibrīzī,

Sharh al-Qașāid al-'Ashr, 10-11.

30 Jones, Early Arabic Poetry, II, 56. 
his beloved at a certain place where once she settled for a while and where her traces have not been completely effaced with the blowing of the wind. He sees her and her tribe's traces at their encampment and on their route. Compared to Stetkevych's readings, this is a very clear picture. Then, what could be an appropriate reason for pushing these opening verses into reading them as representing blood-vengeance, the failure of man/culture, fecundity of nature, the raw and cooked, sexual penetration, and so on? Stetkevych's interpretations do not serve to explain the verses but only present scattered applications of theories.

Stetkevych continues her interpretations in a similar fashion; for instance, she suggests that the word, 'abra muharāqa (poured tears) in verse 6 is simply a substitute for blood vengeance, for the shedding of tears in mourning is metaphorically identified with the shedding of blood in avenging. ${ }^{31}$ Again, I have impatiently checked a number of classical commentaries, but my efforts were in vain. Apparently, none of them could catch such metaphorical identification between pouring tears and blood vengeance. ${ }^{32}$ After all, pouring tears after a lost beloved is a very common and traditional way of expressing grief, yearning, and longing for the lover in many literary traditions. In the case of the Mu'allaqa of Imru' al-Qays as well, it makes very good sense if we consider this image in the same pattern. Consequently, in order to make them comparable to the blood vengeance ritual, Stetkevych pushes such literary conventions in uncommon and complicated directions. Likewise, it is not easy to know exactly if the Șu'lūk poet she examines in the previous article was a passenger manqué or not, but it is indeed the reader who has gradually become a poor passenger manqué (dillil) between Stetkevych's lines. Theoretical and logical connections in her explanations have become unclear to the reader, as in the case of the connection between the pouring tears and blood vengeance. In fact, the reader is not able to achieve reaggregation and reintegration into Stetkevych's conclusions, as the difficulties of the reader's cureless liminal state becomes her/his permanent mental state and thus s/he constantly recalls, fa hal 'inda rasmin dārisin min mu'awwali (is there anyone to give me support at traces effaced?) (verse 6).

Stetkevych invites testimonies from the Garden of Adonis to interpret rayya al-qaranful (fragrance of cloves) of verse 8 as an image of illicit eroticism. She similarly analyzes huddāb (fringes) of verse 12 in the light of

31 Stetkevych, The Mute Immortals Speak, 261.

32 Al-Anbārī, Sharh al-Qașā̉id al-Sab al-Ṭiwāl al-Jāhiliyyāt, 25-27; al-Naḥhās, Sharh alQașāid al-Tis' al-Mashhūrāt, 104-105; al-Zawzanī, Sharh al-Mu'allaqāt al-Sab', 9; alTibrīiē, Sharh al-Qașāid al-'Ashr, 13-14. 
Freudian psychoanalysis as a metaphor for infantile sexuality as opposed to adult sexuality. ${ }^{33}$ The scent of musk coming through the east wind (nasim) is a traditional poetic expression for a description of the beloved, and in general, it is not considered a sexual metaphor for her, rather it is regarded as an innocent symbol expressing the poet's longing. In verse 8 as well, the poet remembers his beloved for whom he pours tears (verse 6) and his tears streamed down his neck until the tears wet his sword-strap (verse 9). Such tears do not seem to be an image of illicit eroticism. As for the word huddāb, according to classical commentators in general it is a collective meaning for "fringes." 34 The poet remembers his joyful days, especially a day at Dārat Juljul (verse 10) when he hamstrung his camel for the young unmarried women ('adhārā) (verse 11) who kept throwing its flesh and fat that looked like the twisted fringes of silk cloth (verse 12). The connection between the $h u d d \bar{a} b$ and Freudian infantile sexuality does not seem to be a convincing one. If she had made that comparison particularly through the 'adhārā (maidens, virgins), her argument might have had a more understandable logical link. Even such a connection, however, would not necessarily imply an infantile sexuality, because the poet is naturally attracted to young women rather than older ones and he recalls them. The longing for the young women does not necessarily insinuate that his affair with them is an infantile one. As for the case of the word fringes ( $h u d d \bar{a} b$ ), the connection to Freudian infantile sexuality is even a more distant one, and it does not seem to be an appropriate application.

As for verses 16 and 17, considered among quite scandalous pieces in the classical poetic canon of the Mu'allaqa, Stetkevych asserts that the details of the lines enhance "the illicit and antisocial aspect of the liminal erotic encounter." 35 For in Bedouin society it is believed that sexual intercourse with a nursing mother is harmful to the nursling. Not only does she endanger her children, born and unborn, but also she betrays her husband, the father. ${ }^{36}$ Stetkevych further calls attention to the parallelism between the qualities of the beloved described in the lines 37 and 38 and the seductive eroticism of Aphrodite. ${ }^{37}$ She seems to be aware of the inconsistency in her argument when she admits that although the nasi $b$ section of

33 Stetkevych, The Mute Immortals Speak, 262-263.

34 Al-Anbārī, Sharh al-Qașāì al-Sab al-Ṭiwāl al-Jāhiliyyāt, 35; al-Naḥhās, Sharh al-

Qașāìd al-Tis' al-Mashhūrāt, 116; al-Zawzanī, Sharh al-Múallaqāt al-Sab́, 11; al-Tibrīzī,

Sharh al-Qașầid al-'Ashr, 23.

35 Stetkevych, The Mute Immortals Speak, 265.

36 Stetkevych, The Mute Immortals Speak, 265.

37 Stetkevych, The Mute Immortals Speak, 269. 
the qasiida exhibits many of the characteristics of both separation and the liminal phase of the ritual paradigm, nevertheless, it does not comprise any progression. The poet is still disconsolate, and the section ends as it began. This lack of progression contradicts the liminal phase of the ritual paradigm. ${ }^{38}$

Stetkevych continues surprising the reader when she argues that the night-day imagery in line 46 should remind us of blood vengeance. ${ }^{39}$ But why and how? Once again, the reader does not have any satisfactory explanation for the connection between these two well-known classical counterpart words and blood vengeance. Evidently, the poet calls upon the long night to give way to morning, though the dawn will be no better for him (alā ayyuhā-l-laylu-t-țawìlu alā-njali, bi șubḥin wa mā-l-'iṣbāḥu fì-ka bi amthali). The verse describes the desperate situation of the poet and does not include any reasonable implication of blood vengeance. ${ }^{40}$

According to Stetkevych's explanations, the hunt (64-67) and cooking of the meat for the feast (68) signal the "invigoration and jubilation" of the plerosis phase of Gaster's seasonal pattern, because the hunt and feast indicate aggregation and the commensal meal that celebrates it. ${ }^{41}$ As for the final section of the qașida depicting the power of a devastating thunderstorm, Stetkevych asserts that this scene is "a subliminal or metaphorical expression of the achievement of blood vengeance, that this is the root meaning from which this extended description and its particular imagery derive." 42 Thus, she concludes, "the effect of substituting the storm scene for the battle scene is to raise the level of poetic discourse from the heroic to the cosmic or mythic." 43 This scene elevates the poem from the tribal to the universal. It is at this mythic level that Imru' al-Qays becomes a disinherited errant monarch who loses his patrimony. Furthermore, for Stetkevych, dying in a Byzantine robe, Imru' al-Qays loses his self and soul, and abandons his Arabic identity at the same time. ${ }^{44}$

38 Stetkevych, The Mute Immortals Speak, 270.

39 Stetkevych, The Mute Immortals Speak, 271.

40 Al-Anbārī, Sharh al-Qașāid al-Sab al-Ṭiwāl al-Jāhiliyyāt, 77; al-Naḥhās, Sharh al-

Qașāid al-Tis' al-Mashhūrāt, 160-61; al-Zawzanī, Sharh al-Mu'allaqāt al-Sab', 27; al-

Tibrīzī, Sharh al-Qașäid al-'Ashr, 52.

41 Stetkevych, The Mute Immortals Speak, 277.

42 Stetkevych, The Mute Immortals Speak, 279.

43 Stetkevych, The Mute Immortals Speak, 280.

44 Stetkevych, The Mute Immortals Speak, 284. 
In her closing remarks, Stetkevych asserts,

It was the very power of pre-Islamic poetry that prepared the Arabs culturally and linguistically for the literary miracle of the Qur'ān, but it was precisely that power, too, which, if it did not submit to Islam, would challenge it and therefore be condemned. It comes as no surprise, then, that the greatest of the Jähili poets was, ipso facto, also the 'damnedest'-or, in the words of the Prophet Muhammad, that Imru' al-Qays is 'the leader of the poets into hellfire. ${ }^{45}$

\section{Condemnation of Poetry}

As a literary art, however, the power of pre-Islamic poetry is not condemned in primary Islamic sources. Even in the well-known Qur'ānic verse (Q.26:224-27), it is not poetry, nor the poets individually that are criticized. The last verse of the süra clearly indicates that only a specific type of poet is addressed. Accordingly, the Prophet Muhammad appreciated and awarded the poetic power of Ka'b b. Zuhayr, and he personally was very sympathetic to other poets, such as Hassān b. Thābit and 'Abd Allāh b. Rawāḥa, of his time. As long as they did not attack the new religion and his Prophet, poets were treated as any other ordinary member of society.

In addition, the early Islamic criticism of poets has another historical and religious dimension beyond Stetkevych's argument. In the early times of his prophethood, Muhammad was accused by his opponents of being a poet (shā'ir) inspired by a demon (shayțān), a soothsayer (kāhin) under the influence of various idols (aṣnām), and as a madman (majnūn) possessed by jinn. The Qur'ānic stress against such accusations falls on the divine origin of the Qur'ān. Refusing the ideas of the Prophet's opponents, the $\bar{a} y \bar{a} t$ affirm that Muhammad is neither a soothsayer, nor a madman, nor a poet (Q.52:29-31). Rather, his message is a revelation from God (Q.69:40-43). Therefore, the main Qur'ānic point is not to criticize the power of poetry, nor the poets' artistic excellencies, but to clarify the exclusive and intrinsic nature of Qur'ànic revelation, being the word of God (Kaläm Allah), not that of a man.

Furthermore, in contrast to Stetkevych's assertion, the Qur'ān is not uncomfortable with any poetic challenges. Rather, it itself invites opponents to compose such verses declaring, "bring forth one süra like those of the Qur'ān" and urging them "to call upon anyone except God" to achieve this

45 Stetkevych, The Mute Immortals Speak, 284-85. 
(Q.2:23). This is the very idea of the Qur'annic challenge (tahaddī), on the basis of which later Muslim philologists began to write on the stylistic excellence of the Qur'ān, and presented a sizable literature, known as i'jāz alQur'ān (inimitability of the Qur'ān) emphasizing the different aspects of miraculousness of the Holy Book.

As for Imru' al-Qays' individual case, I do not think that the supposedly Prophetic declaration about him is based on his poetic power. Instead, he was the prototype of Jâhili immorality. He was a representative personality of illicit love affairs, excessive blood vengeance, disobedience, and the like. Thus, he possessed almost all the negative characteristics attributed to the Jähili era that were condemned even in pre-Islamic Arabian societies, and that the new religion came to abolish. This must be the very reason for which his name was singled out in Islamic narrations.

It should also be mentioned that despite its high currency as a statement attributed to the Prophet Muhammad in literary circles, none of the six famous Hadith collections (al-Kutub al-Sitta) include this declaration. It is Ahmad b. Hanbal (d. 241/855) who relates this statement (Imru'u-l-Qaysi hāmilu liwā'ish-shi'ri ilā-n-nār) in his al-Musnad. Many Hadìth authorities including alTabarānī (d. 360/971), Ibn Kathīr (d. 774/1373), al-Haythamī (d. 807/1405), and Ibn Hajar (d. 852/1449) examine the soundness of this expression and conclude that it is not a reliable one (wa huwa hadithun da'ifun; wa huwa khabarun bātilun.) Muslim historical practice as well testifies that the artistic ingeniousness of Imru'al-Qays has always been appreciated. ${ }^{46} \mathrm{He}$ has been copiously quoted not only in literary works but also in purely religious-oriented presentations. His utterances have been extensively used to explain ambiguous Qur'ānic and Prophetic statements. Consequently, in both supposed casesi.e., whether Imru' al-Qays was condemned by the Prophet or not-he has never been considered a potential literary challenger to the Qur'ān so that he was supposed to be condemned and eliminated as Stetkevych argues.

\section{The Bānat Su'ād of Ka'b b. Zuhayr in Context}

In her article, "Pre-Islamic Panegyric and the Poetics of Redemption,"47 Stetkevych proposes another example of a "fresh" reading for the classical Arabic qașida. In this case, she examines the poems by 'Alqama b. 'Abada and $\mathrm{Ka}$ 'b b. Zuhayr. She focuses on two main issues appearing to have dogged

46 See editor's note in al-Ṭūî, Mawā'id al-Hays fì Fawāid Imri' al-Qays, 121-22. 47 Stetkevych, "Pre-Islamic Panegyric and the Poetics of Redemption," 1-57. 
the qașida throughout the centuries by Arab and Orientalist literary critical tradition. These two issues concern the integrity of the poet and of the poetic form respectively. The first raises the question of the poet's sincerity since the preeminent position of the panegyric mode (madih) and tribal boast (fakhr) was closely connected to the caliphal and princely compensations of the panegyrists. Thus, the accusation appeared that the poet's encomia were mere sycophantic blandishment. The second issue, formulated by the famous 'Abbāsid critic Ibn Qutayba, concerns the main purpose or goal of the qașida. According to Ibn Qutayba's argument, the third and final (madih section of the qașida is the primary object of the composer, whereas the $n a s i b$ and rahil sections are the means or introductory rhetorical sections to the madih. ${ }^{48}$ To challenge these two arguments, Stetkevych asserts, "I have posited first a function for the panegyric qașida, that of a commodity in ritual exchange, and second, a ritual form or structure, that of the seasonal rite." ${ }^{49}$ As far as its structure is concerned, it is interesting that Stetkevych chooses one of the best examples of the qașida, which itself conforms to Ibn Qutayba's very qașìda description. Because Ka'b b. Zuhayr’s Bānat Su'äd has quite well-organized sections: a nasīb describing the beloved's beauty and

48 "I have heard from a man of learning that the composer of Odes began by mentioning the deserted dwelling-places and the relics and traces of habitation. Then he wept and complained and addressed the desolate encampment, and begged his companion to make a halt, in order that he might have occasion to speak of those who had once lived there and afterwards departed; for the dwellers in tents were different from townsmen or villagers in respect of coming and going, because they moved from one waterspring to another, seeking pasture and searching out the places where rain had fallen. Then to this he linked the erotic prelude (nasib), and bewailed the violence of his love and the anguish of separation from his mistress and the extremity of his passion and desire, so as to win the hearts of his hearers and divert their eyes towards him, since the song of love touches men's souls and takes hold of their hearts, God having put it in the constitution of His creatures to love dalliance and the society of women, in such wise that we find very few but are attached thereto by some tie or have some share therein, whether lawful or unpermitted. Now, when the poet had assured himself of an attentive hearing, he followed up his advantage and set forth his claim: thus he went on to complain of fatigue and want of sleep and traveling by night and of the noonday heat, and how his camel had been reduced to leanness. And when, after representing all the discomfort and danger of his journey, he knew that he had fully justifies his hope and expectation of receiving his due meed from the person to whom the poem was addressed, he entered upon the panegyric (madih), and incited him to reward, and kindled his generosity by exalting him above his peers and pronouncing the greatest dignity, in comparison with his, to be little." Ibn Qutayba, al-Shi'r wa al-Shu'arä, 20-21. (trans. Nicholson, A literary History of Arabs, 77-78). For a discussion of this passage in modern studies, see Montgomery, "Of Models and Amanuenses, 1-47. I owe this last reference to the anonymous reviewer of the article.

49 Stetkevych, "Pre-Islamic Panegyric and the Poetics of Redemption," 1. 
fickleness; a rahìl with the detailed portrait of a noble and swift she-camel; a madih containing the poet's excuse; and, connected through a lion episode, a very short eulogy of the Prophet Muhammad and his tribe Quraysh in traditional Jähilī fashion. So far as her argument is concerned, however, this may not be taken as a self-contradictory point, because she tries to question Ibn Qutayba's statement that the purpose of the qașida is the madih section, rather than his formulation of the qașida. Nevertheless, since she proposes a "new estimation of the structure of the qașida" 50 in contrast with Ibn Qutayba's formulation, her choice of the poem on the basis of which she elaborates her argument does have an incoherent dimension.

Stetkevych's main point in these two poems is that they are not merely eloquent metered and rhymed panegyrics but serve in fact as exchange commodities in the redeeming of human life, as ransom payments. Doing this, she analyzes both internal testimonies in the poems and external evidence in the akhbär related to these poems. She proposes that in light of her main point we can achieve a "new understanding" of the ritual function of poetry in pre-modern societies and a "new estimation of the structure of the qașida." She further tries to demonstrate that it is its function that ultimately determines the aesthetic aspects of the poem. The first poem, a composition of 'Alqama, is said to have served as a ransom for captive kinsmen. The second one, the Bānat Su'ád by Ka'b b. Zuhayr on which henceforth I will primarily focus, is said to have been presented to the Prophet Muhammad on the occasion of Ka'b's apology and conversion to Islam. Upon Ka'b's recitation of the poem, it is related that the Prophet awarded the poet with his own mantle (burda). ${ }^{51}$ The first poem, therefore, symbolizes the redemption of a mortal soul, and the second an immortal one. ${ }^{52}$

Stetkevych analyzes the akhbār accounts associated with the Bānat Su'àd alongside the internal evidence in the qașida and reaches the conclusion that the poem functioned as a redemption payment for the poet's own life. Consequently, she asserts, the poem symbolizes the poet's transfer of allegiance from the expiring tribal ethos of the Jähilìyya to the victorious Prophet of the new religion. ${ }^{53}$

50 Stetkevych, "Pre-Islamic Panegyric and the Poetics of Redemption," 2.

51 Treating it with skepticism, not every commentator mentions the burda episode in their writings. For example, Ibn Hishām does not talk about the burda story at all. Ibn Kathir states, "And this is an extremely widespread story, but I find nothing of it in the more widely circulated collections with an isnād that I would trust." Sells, "Bānat Su'äd: Translation and Introduction," 141.

52 Stetkevych, "Pre-Islamic Panegyric and the Poetics of Redemption," 2.

53 Stetkevych, "Pre-Islamic Panegyric and the Poetics of Redemption," 21. 
According to the akhbār, ${ }^{54}$ upon his brother Bujayr's conversion to Islam, Ka'b got angry with him and sent him a message comprising a bitter attack of the Prophet. When Ka'b's verses reached his brother, he informed the Prophet about the matter and replied to his brother declaring the truthfulness of Islam and untruthfulness of his former beliefs. Ka'b's attack to the Prophet brought about a bitter and angry reaction from the Muslim society. Bujayr's message and the declaration about him distressed Ka'b greatly, and he tried to find some solution in order to save his situation, but all possible protectors, including his own tribe, refused to shelter him. He finally decided to go to Medina in order to seek a way to save his life.

Then he came to the Apostle of God. The Prophet did not know him, so he sat down before him and said, 'O Apostle of God, if Ka'b ibn Zubayr were to come to you repentant and submitting to Islam, would you accept him, if I brought him to you?' 'Yes,' he replied. Then he said, 'I am Ka'b.' Suddenly, one of the Anșār leapt up and cried, 'Let me cut off his head!' But the Prophet restrained him, whereupon Ka'b recited his panegyric to the Prophet. 55

These akhbār accounts are supported by internal evidence in the qașida itself. For example, line 32 deals with how the situation becomes clear to the poet when his own tribesmen consider him "as good as dead (maqtūl)"; line 33 implies how his tribesmen disown him, and they neither defend nor avenge him; line 36 entails how he hopes for a pardon from God's Messenger (Rasūl Allāh), and so on. Thus, the akhbār function as a sort of commentary on the qașida.

54 For the $a k h b \bar{a} r$ accumulated around Ka'b b. Zuhayr, see Abū al-Faraj al-Isfahānī, Kitāb al-Aghānī, XVIII, 6358-6371; al-Tibrīzī, Sharh Qaṣidat Ka‘b b. Zuhayr, 10-11; al-Sukkarī, Dìwān Ka'b b. Zuhayr, 1-3; editor's introduction in Ibn Hishām, Sharh Qașïdat Bānat Su'ād, 9-12; Husain, "Bānat Su'äd of Ka'b bin Zuhair," 67-70; Redhouse, "The Burda, i.e., the Poem of the Mantle by Ka'b , Son of Zuhayr," 307-311. For the translation, a detailed analysis, and interpretation of the various versions (riwāya $\bar{t}$ ) of the akhbār related to Ka'b b. Zuhayr and the historical background of the Bānat Su'âd, see Zwettler, "The Poet and the Prophet," 313-87. Zwettler's article does not deal with the poem itself, but with the narrative reports of the meeting of Kacb and Prophet (p. 313). He analyzes the bodies of the variants of the story in the reports of Ibn Ishāq, Ibn Sallām, and alHizāmī and singles out certain discussions on some parts of the story. For example, he presents an extensive examination of al-ma'mūn - al-ma'mūr issue, i.e., whether Ka'b used the word al-ma'mūr (the bidden one) implying the Prophet Muhammad was under the influence of jinn as other poets and soothsayers (kuhhann) of his time, or he just used the word al-ma'mūn (the entrusted one) (pp.330-334).

55 Stetkevych, "Pre-Islamic Panegyric and the Poetics of Redemption," 21-22. 
Stetkevych considers the poem as a ransom payment. James E. Montgomery classifies it as a panegyrical itidhār (a poem of apology) resembling alNābigha al-Dhubyānì's poem addressed to the Lakhmid prince al-Nu'mān. ${ }^{56}$ Stetkevych's classification of the qaṣida seems to be a reductionist evaluation. Given the akhbār associated with the poem, the Prophet had already accepted his apology before he began his recitation. Thus, the poet had already reached his goal, and he had nothing more to expect in return. He did not need to give a ransom payment. At the same time, although in general I agree that there is a close relationship between Ka'b's composition of the poem and his search for an apology, there must also be some kind of relationship between the composition of the poem and the very instant he recited it before the Prophet Muhammad. For given the akhbār and internal evidence in the qașida, they both imply that at least the section in which Ka'b praises the Muhājirūn, unlike the Anșār, has something to do with this very instant. Therefore, I cannot argue that the poem is entirely an improvised composition just in front of the Prophet; however, neither am I inclined to deny the partial influence of the actual conditions on the qașida that we have today.

As for Stetkevych's analysis of the Bānat Su'äd, she begins her comments with the name Su'àd. Given the derivation of the name Su'a d from the root $s^{-}-d$, whence $s a$ 'a $d a$ - prosperity, good fortune, happiness, felicity-she proposes the possibility of reading the Bānat Su'àd (Su'ād has departed) as an elegy to the Jähilìyya. According to her explanation, the poet invokes his life experience in the previous bygone Golden Age such as his political situation, happiness, good fortune, and the like. But now he has been abandoned and betrayed by his kinsmen. Similarly, she asserts, the expression, lam yufda (unransomed, unredeemed), or, as another variant of it, lam yujza (unrequited) (line 1), refers to his tribe's failure in fulfilling the customary duties for him. ${ }^{57}$ This seems to be, perhaps philologically related, but contextually and traditionally an incomprehensible argument. Above all, commencing a poem with the expression Bānat Suād is a traditional fashion of composition; for instance, according to Hidāyat Husain's report, in his Tabaqāt alnuhāt, al-Tirmidhī mentions that Bundār al-Iṣfahānī (d. 252/866) knew by heart about 900 poems-although we are not supposed to take the number

56 Montgomery, The Vagaries of the Qasidah, 222-23.

57 Stetkevych, "Pre-Islamic Panegyric and the Poetics of Redemption," 30. Similarly, she approves the word Beatrice as a translation for Su'äd and she gives credit to Hidāyat Husain for this translation. She appears to be unaware of the original translator, Redhouse in doing this. In fact, in most cases, Hussain simply gives Redhouse's translation with some minor modifications of his. See Redhouse, "The Burda, i.e., the Poem of the Mantle by Ka‘b , Son of Zuhayr," 303- 318. 
literally-beginning with the Bānat Su'ād. Even Ka'b’s father, Zuhayr, composed poems commencing with this very expression: "Su'äd has departed and her cord (of affection) is severed. Would that the bond uniting her to me might be restored." 58

For the closing line of the nasīb, Stetkevych argues that the words abätīlu (empty prattle) (line 10) and tadlilu (delusion) (line 12) have an eminently Qur'ānic resonance. The former is associated with Qur'ānic bāțil (false, falsehood, vanity, lie) and thus with $k u f r$ (disbelief) and in opposition to haqq (truth) and ni'mat Allāh (God's blessing) (Q.31:30; 22:62, etc). The latter is related to Qur'ānic dalla/yadillu (to stray, err), and thus to kufr (unbelief), shirk (polytheism), and zulm (oppression, injustice) and in opposition to hudā (right guidance) (Q.41:1; 13:14; 34:24, etc). On the basis of this etymological Qur'ānic resonance, Stetkevych draws the conclusion that using these words, the poet refers to his kinsmen's failure to fulfill the obligations of Jähili virtues (murü'a) and the bankruptcy of ancestral ways. Thus these two words, abātīl and tadlìl, are equatable with the Qur'ānic kufr and shirk. This relationship enables Stetkevych to invite attention to Gaster's aforementioned theory. Thus, in terms of Gaster's seasonal pattern, the nasib section of the qașida represents an expression of the mortification phase. "The seasonal breakup of the transhumant tribes marks the end of one 'lease on life' and the 'new lease' is not yet assured; at the same time the broken vow and unfulfilled promise mark the dissolution of the Jähilī'social contract." 59

In the context of the qașìda, however, abātîl and tadlìl make quite reasonable sense when we consider them as certain characteristics of the Su'äd, for she is unreliable (law annahā șadaqat ma wa'adat) and resistant to advice (law anna-n-nuṣha maqbūlu) (line 6); the calamity (faj), mendacity (wal),

58 Husain, "Bānat Su'âd of Ka'b bin Zuhair," 71.

59 Stetkevych, "Pre-Islamic Panegyric and the Poetics of Redemption," 31. Furthermore, Stetkevych argues that the she-camel described in the rahil section embodies the "liminal" qualities of the poet/passenger himself who must make a transition from the law of his own tribe to the law of Prophet Muhammad. She continues, "Line 26 [On a day when the chameleon is as burnt as if -his sun-scorched parts were bread baked on hot rock] alludes, in the Levi-Straussian language of 'the raw and the cooked,' to the purifying, purgative aspect of the liminal journey through a transubstantiation from living flesh to baked bread, from nature to culture. The effect of heat and hardship is to weed out the weak and unfit; the strong survive, but transformed and reborn. The raw (=nature) chameleon scorched by the sun is metaphorically metamorphosed into the cooked (=culture) (mamlül refers to bread or meat baked in embers or on heated rocks)." (p. 32). Similarly, she invites attention to the parallelism between the lamenting women in the lines 29-32 and Gaster's reports on the practice of howling and lamenting at seasonal ceremonies of Mortification in the Ancient Near East. (p. 33) 
inconstancy (ikhlāf), and perfidy (tabdìl) (line 7) are ingrained in her blood [like her second nature,] shifting through various forms, images, and guises (dhāt al-alwān or dhū lawnayn), she reminds the lover of the ghül (a certain kind of jinn or demon) (line 8), and her promises are like those of 'Urqūb (line 10). ${ }^{60}$ These characteristics naturally imply that her premises are nothing except empty prattle ( $a b \bar{a} t \underline{i} \bar{l})$, which will remain forever unfulfilled (line 11). The lover is not supposed to let himself be deceived because hopes and dreams are a mere delusion (tadlill). Hence in itself, the nasîb describing the beloved's beauty and falseness makes very comprehensive, picturesque, and straightforward sense, while Stetkevych's explanations appear to push it into unnecessarily intricate directions. Moreover, the verses imply that all these similes are just a likeness of Su'a d, being herself beyond all such description. ${ }^{61}$

According to Stetkevych's writings, the transitional lines (takhalluṣ) from the $n a s i \bar{b}$ to the rahil (lines 13-14) most persuasively confirm her reading. She asserts,

60 According to the story, 'Urqūb is the name of a person marked for breaking his premises. "The reason is that he had a date tree in Yathrib and he promised his brother to give him the fruit and asked him to come when the tree should blossom. His brother came as promised but 'Urqūb told him to come when the fruits should become balah (unripe dates) being in the middle state between khalal and busr which signify also unripe dates in different stages. His brother went there as directed but was again told to come when the dates should be zahw (yellowish-red). His brother came, but he was told to come when the dates were rutab (ripe). He came at the appointed time, but was asked to come again when the dates were dry. This time 'Urqūb secretly took down all the dates at night, and did not give anything to his brother. For this reason his name has become proverbial for falsehood, and many Arab poets have quoted his name for falsehood." Husain, "Bānat Su'ād of Ka'b bin Zuhair," 74. For slightly different versions of the story regarding 'Urqūb, see al-Tibrīzī, Sharh Qașidat Ka'b b. Zuhayr, 17; al-Sukkarī, Dìwān Ka'b b. Zuhayr, 4-5; Ibn Hishām, Sharh Qaṣìdat Bānat Su'ād, 100.

61 For a detailed description for the Su'âd's disposition, see Husain, "Bānat Su'àd of Ka'b bin Zuhair," 73. Husain interprets Ka'b's metaphorical expressions for the Su'äd in line 3-4, "When she smiles she displays side teeth wet, as if with a first draught of wine or with a second. Mixed with cool water from a wadi's bend, in a pebbled streambed limpid, sparkling in the forenoon sun, chilled by the northwind." Husain comments, "There are six characteristics of the water that is mixed with the wine: The first, its coolness; the second, that is taken from a winding stream, because the blowing of the wind from all sides purifies and makes the water cool; the third, that is pure and free from mud; the fourth, that is taken from a broad pebbly channel, which being broad contains cool water, and whose pebbles purify the water; the fifth, that is taken during the forenoon because then the sun's rays have not made the water warm; the sixth, the North wind has blown upon it, as the North wind makes water cool in Arabia." In Husain view, the poet has all these in his mind while doing his description. Husain, "Bānat Su'ād of Ka'b bin Zuhair," 73. 
Whereas we normally find the poet eschewing the distant and unattainable mistress and declaring his intention to seek his fortune elsewhere (as 'Alqamah's qașida), line 13 of Ka'b poem states quite precisely that it is to regain 'Su'a d' that he undertakes the desert journey. This only makes sense, both poetically and politically, if we take this mean to a 'new Su'äd,' the 'prosperity, good fortune, and felicity' of Islam. ${ }^{62}$

It is surprising that on the basis of these lines, Stetkevych considers the poet quite hopeful to attain his beloved. Unlike Stetkevych's argument, I think Ka'b's main stress in these lines falls not on the attainability of his mistress, but rather on the overwhelming difficulty of reaching her. The beloved is in a land not quite reachable (bi-ardin la yuballighuhāa) and in order to reach her, the lover must undertake extraordinary tasks, which in this particular case include finding an exceptional (almost purely imaginary) she-camel. Given my readings of pre-Islamic poetry, I would call the takhalluṣ lines in this qaṣida among the most exquisite examples of their genre. They are quite flowing and link the sections of the qașida to each other in a very meaningful and eloquent way. For instance, when the poet describes the forelegs and galloping of the she-camel and compares this scene to the arms of a wailing woman upon receiving the news that her firstborn child has died (lines 27-31), he presents a picturesque scene. I would not be inclined to interrupt the original semantic and structural completeness and fluency of the qașida through such artificial readings as Stetkevych suggests.

Stetkevych makes a compelling point when she invites attention to the possibility that the poem itself, especially lines 32-41, might be the narrative source of the $a k h b \bar{a} r$ associated with it. It does not seem unlikely that $a k h b \bar{a} r$ are a secondary derivation from the poem itself. ${ }^{63}$ She further considers lines 32-41 as a "Filling" for lines 6-11 which she calls "Emptying." She asserts that the qualities mentioned in lines 6-11-mendacity, inconstancy, perfidy, the failure to fulfill the promises-serve as the Emptying elements for the abrogation of the Jähili social contract. Section 32-41 constitutes the fulfillment of the nasib; a number of antitheses indicate this relationship, such as "her promises were nothing except empty prattle" ( $m \bar{a}$ mawā' $\bar{i} d u h \bar{a}$ illā-l-abàtīlu) of line 11 and "his word is the word" (qiluhī al-qìlu) of line 41, the delusion and misguidance (tadlīl) of line 12, and right guidance (hadō) of line 37. Therefore, Stetkevych asserts, the movement from Emptying to Filling is

62 Stetkevych, "Pre-Islamic Panegyric and the Poetics of Redemption," 31. 63 Stetkevych, "Pre-Islamic Panegyric and the Poetics of Redemption," 34. 
expressed in a variety of ways in the two sections. ${ }^{64}$ Likewise, for the closing lines of the qașida (54-55), she argues that the phrase hiyäd al-mawt (pools of death) alludes to the "devitalization or mortification," most often of the enemy in pre-Islamic times. From the Muslim's point of view, however, the same phrase refers to death in battle "in the way of God" (fì sabill Allāh) that guarantees salvation and life everlasting, and thus, Stetkevych concludes, in terms of the ritual patterns, the death of a martyr conforms to "revitalization and invigoration." ${ }^{65}$ I would classify these lines as good examples for munsifät (fair/equitable poems) because the Muhājirūn are described as being softhearted and they are not joyful when their lances wound their enemies, or Ka'b simply praises them in a traditional madih fashion. It seems that the poet's main stress falls on the gentleness and bravery of the Muhäjirūn. They never run away from battle, the lances strike their breasts and throats, and not their backs. Unlike Stetkevych's argument, it does not seem that Ka'b implies the evolution of the hiyā al-mawt from Jähilīyya to Islam.

\section{Conclusion}

Despite the sustained and admirable efforts of Stetkevych in trying to integrate pre-Islamic Arabic poetry into world literature, her arguments based on the paradigm of the "rite of passage" entail some cumbersome and inapplicable conclusions. This is evidently due partly to the radical differences between peculiarities of the ancient Bedouin poetry and the aforementioned modern Western literary traditions (mainly based on anthropological theories) and their rhetorical elements. For, as she has already accepted, the relationships between the image, theme, and structure in the Jähili qașìda are complex metaphorical ones often operating on several semantic levels. They are dependent upon an intricate interplay between traditional imagery and ritual. The arbitrary classification and comparison of Bedouin poetic elements may not serve any purpose other than basically deteriorating their original meanings.

Stetkevych often introduces arguments that are, in the final analysis, similar to those she criticizes. Her suggestions generally do not serve to explicate the verses so much as introduce further complexity. An example includes her argument that the opening lines of the Muallaqa of Imru' al-Qays imply the blood-vengeance, the failure of man/culture, fecundity of nature, the raw and cooked, and so on. Likewise, her reading of the poetic metaphor of the

64 Stetkevych, "Pre-Islamic Panegyric and the Poetics of Redemption," 37. 65 Stetkevych, "Pre-Islamic Panegyric and the Poetics of Redemption," 39. 
"pouring tears," and convention of the counterpart words "day and night" as referring to blood-vengeance, do not present concise or original statement. By pushing such traditional rhetorical figures in uncommon and unnecessary directions, she creates new ambiguities without offering any convincing explanation. Furthermore, some of her arguments entail contradictory characteristics, as in the case of her questioning Ibn Qutayba's formulation of the classical qașida structure, but still on the basis of an example that, in fact, conforms to Ibn Qutayba's formulation.

She seems to underestimate the artistic qualities of the poems when, for instance, in the example of Bānat Su'äd, she tries to demonstrate that it is the very function of a poem that ultimately determines its aesthetic aspects. I do not think that Bānat Su'ād became widespread in literary circles because of its function as a ransom payment or as a praise poem for the Prophet Muhammad. After all, beyond its ritual function and historical and religious peculiarity, this poem is a piece of art and one of the most exquisitely beautiful specimens of Arabic poetry. Therefore, Stetkevych's argument in this regard appears to be quite a reductionist evaluation.

I am not arguing that classical Arab commentators have done everything that could be done to explain Jähili poetry. But disregarding their efforts may result in some artificial conclusions as in the case of Stetkevych's interpretations of the Bānat Su'äd as an elegy to bygone Jähilìyya. Commencing poems with the expression Bānat Su'äd was a common poetic convention in preIslamic Arabic poetry, and this tradition is explained by indigenous literary authorities. Moreover, in order to make them comparable to Western literary elements, she pushes some pre-Islamic Arabic literary conventions into unnecessarily complicated directions; for instance, in order to construct a parallelism between the mortification phase of Gaster's theory, she introduces some etymological interpretations regarding the words abātîlu and tadlìlu, which again result in convoluted and inapplicable conclusions. Likewise, the metaphor of the "lamenting woman" makes better sense in the context of the qașida itself compared to Stetkevych's attempt to make it compatible with the practice of howling and lamenting at seasonal ceremonies of mortification in the Ancient Near East.

It is evident that we need some appropriate literary approaches to explain the significance of many obscure details of imagery and rhetorical elements in the Jähili poetry. Such need, however, is not enough to justify the random application of literary approaches to ancient Arabic poetry. Despite the similarities between the two literary conventions, Jähili poetry, nevertheless, 
has its own individual characteristics distinguishing it from other literary traditions. Consequently, given Stetkevych's aforementioned arguments, her conclusions most often do not appear to be successful applications of literary theories.

\section{Bibliography}

Abu Deeb, Kemal, “Towards a Structural Analysis of Pre-Islamic Poetry," International Journal of Middle Eastern Studies, 6 (1975): 148-184.

Abu Deeb, Kemal, “Towards a Structural Analysis of Pre-Islamic Poetry (II): The Eros Vision," Edebiyāt, 1.1 (1976): 3-69.

Abū al-Faraj al-Isfahānī, Kitāb al-Aghānī, ed. Ibrāhīm al-Ibyārī. I-XXXI, Cairo: Dār alSha'b, 1969-1982.

al-Anbārī, Abū Bakr, Sharh al-Qașāid al-Sab' al-Ṭiwāl al-Jāhiliyyāt, ed. 'Abd al-Salām Muhammad Hārūn, Cairo: Dār al-Maārif, 1963.

Bateson, Mary Catherine. Structural Continuity in Poetry: A Linguistic Study of Five PreIslamic Arabic Odes, Paris: The Hague, 1970.

Bauer, Thomas, "Formel und Zitat: Zwei Spielarten von Intertextualität in der altarabischen Dichtung," Journal of Arabic Literature (JAL), 24 (1993): 117-138.

Bauer, Thomas, "Wie fängt meine Qașida an? Formelhafte und nicht-formelhafte NasìbEinleitungsverse," Zeitschrift für Arabische Linguistik (ZAL), 25 (1993): 50-75.

Haydar, Adnan, “The Mu'allaqa of Imru' al-Qays: Its Structure and Meaning, I, Edebiyāt, 2.2 (1977): 227-61.

Haydar, Adnan, “The Mu'allaqa of Imru' al-Qays: Its Structure and Meaning, II, Edebiyāt, 3.1 (1978): 51-82.

Husain, Hidāyat, "Bānat Su'ād of Ka'b bin Zuhair," Islamic Culture 1 (1927): 67-84.

Ibn Hishām, 'Abd Allāh b. Yūsuf, Sharh Qașīdat Bānat Su'âd, ed. Muhammad al-Ṣabbāḥ. Beirut: al-Maktab al-'̄Alamī, 1996.

Ibn Qutayba, al-Shi'r wa al-Shu'iāā, Beirut: Dār al-Thaqāfa, 1964.

Jacobi, Renate, "The Mute Immortals Speak: Pre-Islamic Poetry and the Poetics of Ritual," Bibliotheca Orientalis 53 (1996): 270-273.

Jones, Alan, Early Arabic Poetry, I-II, Ithaca: Oxford University Press, 1992.

al-Jurjānī, 'Abd al-Qāhir, Asrār al-Balāgha, ed. Hellmut Ritter, Istanbul: Istanbul University, 1954.

al-Khațīb al-Tibrīzī, Sharh al-Qaṣāid al-Ashr, ed. Muhammad Muhyīi al-Dīn 'Abd alHamìd, Cairo: Mațba'at M. 'A. Șubayh, 1962.

al-Khațīb al-Tibrīzì, Sharh Qașìdat Ka'b b. Zuhayr, ed. Fritz Krenkow, Beirut: Dār al-Kitāb al-Jadīd, 1971.

Lord, Albert Bates, The Singer of Tales, Cambridge, Mass.: Harvard University Press, 1997.

Meisami, Julie S., Structure and Meaning in Medieval Arabic and Persian Poetry, London and New York: Routledge, 2003. 
Monroe, James T., "Oral Composition in Pre-Islamic Arabic Poetry," Journal of Arabic Literature (JAL), 3 (1972): 1-53.

Montgomery, James E., The Vagaries of the Qasidah: The Tradition and Practice of Early Arabic Poety, Cambridge, England: Gibb Memorial Trust, 1997.

Montgomery, James E., "Of Models and Amanuenses: The Remarks on the Qasida in Ibn Qutayba’s Kitāb al-Shi'r wa-l-Shu'arā', Islamic Reflections, Arabic Musings: Studies in Honour of Alan Jones, eds. Robert G. Hoyland and Philip F. Kennedy, Cambridge, England: Gibb Memorial Trust, 2004: 1-47.

al-Naḥhās, Ahmmad b. Muhammad, Sharh al-Qașāid al-Tis` al-Mashhūrāt, ed. Aḥmad Khațāāb, Baghdad: Maṭba'at al-Ḥukūma, 1973.

Nicholson, Reynold A., A literary History of Arabs, Cambridge: Cambridge University Press, 1956.

Redhouse, James William, "The Burda, i.e., the Poem of the Mantle by Ka'b, Son of Zuhayr," Arabian Poetry for English Readers, ed. William A. Clouston, Glasgow: Priv. Print [ M'Larn and son], 1881: 305-318, 459-462.

Schoeler, Gregor, “Oral Composition," trans. Alma Giese, Encyclopedia of Arabic Literature $(E A L)$, eds. Julie S. Meisami and Paul Starkey, I-II, London and New York: Routledge, 1988: II, 592-593.

Sells, Michael, "Bānat Su'ād: Translation and Introduction," Journal of Arabic Literature (JAL), 21.2 (1990): 140-154.

Stetkevych, Suzanne P., "Structuralist Analyses of Pre-Islamic Poetry: Critique and New Directions," Journal of Near Eastern Studies, 43 (1983): 85-107.

Stetkevych, Suzanne P., "The Șu 'lūk and His Poem: A Paradigm of Passage Manqué," Journal of American Oriental Society, 104.4 (1984): 661-678.

Stetkevych, Suzanne P., The Mute Immortals Speak: Pre-Islamic Poetry and the Poetics of Ritual, Ithaca: Cornell University Press, 1993.

Stetkevych, Suzanne P., "Pre-Islamic Panegyric and the Poetics of Redemption: Mufaddaliyah 119 of 'Alqamah and Bānat Su'äd of Ka'b ibn Zuhayr," Reorientations: Arabic and Persian Poetry, ed. Suzanne P. Stetkevych, Bloomington and Indianapolis: Indiana University Press, 1994: 1-57.

al-Sukkarī, Abū Sa 'ìd al-Ḥasan b. al-Ḥusayn, Dìwān Ka'b b. Zuhayr, ed. Tadeusz Kowalski, Krakow: Polska Akademia Nauk., 1950.

Toorawa, Shawkat M., "Reorientations: Arabic and Persian Poetry," Journal of American Oriental Society, 117:4 (1997): 759-762.

al-Ṭūfī, Najm al-Dīn, Mawāid al-Hays fì Fawāì Imri al-Qays, ed. Muștafā 'Aliyyān, Amman: Dār al-Bashīr, 1994.

al-Zawzanī, Ḥusayn b. Aḥmad, Sharh al-Múallaqāt al-Sab', Beirut: Dār Bayrūt li-al-Ṭibāaa wa al-Nashr, 1958.

Zwettler, Michael, The Oral Tradition of Classical Arabic Poetry: Its Character and Implications, Columbus: Ohio University Press, 1978.

Zwettler, Michael, “The Poet and the Prophet: Towards Understanding the Evolution of a Narrative," Jerusalem Studies of in Arabic and Islam, 5 (1984): 313-87. 


\section{Applying Modern Literary Theories to Pre-Islamic Arabic Poetry: A Critical Analysis of the "Rite of Passage" Model}

Pre-Islamic Arabic poetry has been analyzed from the perspectives of various modern critical literary theories. It has been subject to manifold critical applications that include oral poetry theories, structuralist and anthropological literary theories. Kemal Abu Deeb, Adnan Haydar and especially Suzanne Pinckney Stetkevych are among the leading representatives of this phenomenon. Abu Deeb and Haydar apply specific structuralist techniques of analysis to the ancient Bedouin poetry, while Stetkevych proposes the paradigm of the "rite of passage" as formulated by Arnold van Gennep as a more applicable method to understanding Jāhili poetry. She further argues that the three parts of the qașida; the nasì b, rahìl, and fakhr correspond to the three stages of the rite of passage; separation, liminality, and reaggregation. This article questions the applicability of such western literary theories in translation and analysis of pre-Islamic Arabic poetry and its rhetorical elements.

Concentrating on Stetkevych's arguments in a more detailed fashion, the article elaborates peculiar characteristics of pre-Islamic Arabic poetry and interrogates the applications of such western literary theories in understanding of this traditional form of poetry. It indicates that arbitrary classification and comparison of pre-Islamic poetical elements may not serve for any purpose other than deteriorating their original meanings and introducing additional complexities. It makes references to a good number of examples from her writings to arrive at the conclusion that for the sake of making certain pre-Islamic literary conventions comparable to western literary elements she pushes rhetorical components of both traditions into unnecessary, incomprehensible and complicated directions.

The article appreciates industrious scholarly attempts at trying to integrate Arabic literature into world literature, but it still invites critical attention to the reconsideration some of their conclusions and generalizations. It revisits these arguments by way of comparing them to classical interpretations by indigenous Arabic literary authorities, especially in the cases of the two classical qasidas, namely the Múallaqa of Imru' al-Qays and the Bānat Su'ād of Ka'b b. Zuhayr. The article also questions Stetkevych's generalizations based on these qașidas regarding the issue of condemnation of poetry in Islam and articulates the contextual and historical peculiarities of this subject-matter.

Keywords: Pre-Islamic Arabic poetry, Qașida, literary theories, literary criticism, Structuralism, anthropological literary theories, Rite of Passage, oral poetry, Mu'allaqa of Imru' al-Qays, Bānat Su'ād of Ka'b b. Zuhayr, condemnation of poetry. 